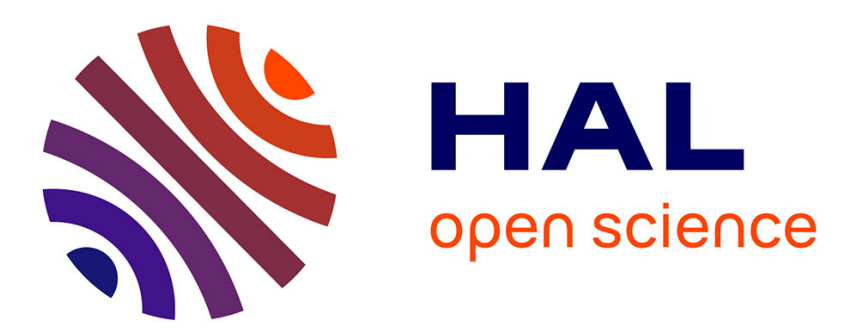

\title{
Characterization and mapping of dwelling types for forest fire prevention
}

\author{
C. Lampin-Maillet, M. Jappiot, M. Long, D. Morge, J.P. Ferrier
}

\section{To cite this version:}

C. Lampin-Maillet, M. Jappiot, M. Long, D. Morge, J.P. Ferrier. Characterization and mapping of dwelling types for forest fire prevention. Computers, Environment and Urban Systems, 2008, 33 (3), p. 224 - p. 232 . 10.1016/j.compenvurbsys.2008.07.003 . hal-00454497

\section{HAL Id: hal-00454497 \\ https://hal.science/hal-00454497}

Submitted on 8 Feb 2010

HAL is a multi-disciplinary open access archive for the deposit and dissemination of scientific research documents, whether they are published or not. The documents may come from teaching and research institutions in France or abroad, or from public or private research centers.
L'archive ouverte pluridisciplinaire HAL, est destinée au dépôt et à la diffusion de documents scientifiques de niveau recherche, publiés ou non, émanant des établissements d'enseignement et de recherche français ou étrangers, des laboratoires publics ou privés. 


\title{
Characterization and mapping of dwelling types for forest fire prevention
}

\author{
Corinne Lampin-Maillet*, Marielle Jappiot*, Marlène Long*, Denis Morge*, Jean-Paul \\ Ferrier ** \\ *: Cemagref, UR EMAX, 3275 route de Cézanne CS40061, 13182 Aix en Provence cedex 5, France \\ **: Aix-Marseille I University, emeritus professor, Aix en Provence, France
}

Corresponding author. Tel.: +33442669963.

E-mail address:corinne.lampin@cemagref.fr

\begin{abstract}
In a context of risk of forest fire, the development of actions concerning wildfire prevention and land management is necessary and essential particularly in wildland urban interfaces (WUI). The term 'WUI' always includes components such as human presence and wildland vegetation. Both the hazard (probability of fire outbreak, distribution) and the vulnerability of urban areas can be characterized through the spatial organization of houses and vegetation. The first step required is to characterize and map WUI in large areas and at a large scale, which, in turn requires qualifying different types of dwellings and mapping them. With this goal in view, the paper presents a brief synthesis of results coming from an exploratory process for the characterization of dwelling types (Lampin et al., 2007), and develops a method based on GISgeo treatments to characterize different types of dwelling with regard to fire risk. Three types of dwellings were classified: isolated dwellings, scattered dwellings and clustered dwellings, using criteria based on the distance between houses, the size of clusters of houses and housing density, which can be mapped automatically. Within dwelling types, the density value of forest fire ignition changed and was twice as high for isolated dwellings as for clustered dwellings. The spatial organization of dwellings seems to have a real impact on fire occurrence. Thus maps of different dwelling types can be interpreted for use in developing fire fighting strategies or prevention actions concerning end-users such as forest and land planning managers or firefighters.
\end{abstract}

KEYWORDS: Spatial analysis, dwelling typology, GIS, forest fire risk, prevention, wildlandurban interface 


\section{Introduction}

Forest fires affect extensive areas and cause serious damage that has ecological, social and economic consequences leading to very high costs of prevention and fire-fighting. Every year more than 2,600 forest fires affect about 24,200 hectares of vegetation in the French Mediterranean region (Promethée database, 1973-2007). Many large fires are linked with the dramatic land transformation that has been taking place in the Mediterranean region for some decades and that is increasing the risk of forest fire. On the one hand, agricultural fallows and orchards are slowly colonized by vegetation, while on the other hand, forest is not sufficiently utilized, where both result in the increased accumulation of fuel load. In addition, especially in the South of France, urbanization coupled with the phenomenon of forest extension is generating new spatial configurations called wildland-urban interfaces (WUI), where WUIs are commonly defined as areas where urban areas meet and interact with rural lands (Vince et al., 2005) creating a new conjunction of housing and vegetation characteristics (Stewart et al., 2007).

In recent decades, there has been a significant increase in housing all around the world (Stewart et al., 2007; Radeloff et al., 2005a). Urban sprawl observed in or near forests represents a significant threat to the environment (Johnson, 2001; Radeloff et al., 2005b). Indeed, it leads to habitat fragmentation (Theobald et al., 1997), threatens wildlife populations by introducing exotic species (Soulé, 1991), and results in a decrease in biodiversity (McKinney, 2002). Alavalapati et al. (2005) summarized the different socioeconomic and environmental concerns in a special issue. However, the main concern in WUIs is wildland fire (Davis, 1990). According to Stewart et al. (2007) "the term wildland-urban-interface is now used almost exclusively in the context of wildland fire". The WUI is becoming a priority area for fire prevention and suppression (Stephens, 2005). Indeed, there is an increasing concern about fuel reduction (Conard et al., 2001), removal of fuel in the immediate vicinity of homes (Cohen, 2000) and plans for emergency evacuation (Church and Cova, 2000). In this way, WUIs have become the central focus of wildland fire policy in Europe as well as in the United States.

We hypothesize that fire behaviour in WUIs is influenced by the pattern of urban areas within a natural landscape. Thus, it is first necessary to qualify and discriminate the spatial pattern of housing units in order to define different classes of houses: isolated dwellings, scattered dwellings or clustered dwellings. There is little literature in Europe about characterization of dwelling types through quantitative criteria in regards to fire risk assessment. For the purposes of this paper, we define 'isolated dwellings' as areas that are not very urbanized and located in a natural space. 'Scattered dwellings' refers to houses spread out over an extended urban area, and 'clustered dwellings' refers to areas where the population is concentrated. Taking into account background methods developed to characterize towns, we develop a method to characterize and stratify urban areas using criteria such as distance between houses, housing density, etc. After a brief synopsis of results stemming from an exploratory process for the characterization of dwelling types, the main aim of the paper is to present a method with which to characterize different types of dwelling with regard to fire risk. This research is a step towards defining the relationship between specific spatial organisation in WUIs and fire behaviour. We use the most efficient method to determine the typology of dwellings and combine this information with the spatial distribution of forest fire ignition points.

\section{Research issues on urban area characterization}

Many studies use land cover data, which can accurately capture high density residential areas but does not work very well in low density residential areas (Ridd, 1995). Census data 
have been widely used to measure urban sprawl in the United States (Theobald, 2001). Census data are collected during surveys and large scale data are easily accessible. According to Stewart et al. (2007), housing density is the most appropriate metric for human presence. In census block groups, housing density has been used to identify WUIs across the US (Stewart et al., 2003). However, there is still a need for thresholds in defining urban, WUI, and wildland areas on the basis of housing density. Depending on the definition provided by different authors, different classes of housing density are reported (Theobald, 2001; Stewart et al., 2003; Stewart et al., 2007; Hammer et al., 2004; Curtis et al. 1995). Kamp and Sampson (2003) used population density instead of housing density to define the potential WUI area in the middle of a density spectrum, which varies from 40 to 400 people per square mile. However, according to Alberti et al. (2007), these metrics do not discriminate well between different landscape patterns, essentially because the number of housing units has increased at a faster rate than that of the human population (Lepczyk and Hammer, 2007; Stewart et al., 2007). Theobald and Romme (2007) developed a method for mapping the WUI at the national scale using housing density but indicated that for planning and management activities, more detailed data are necessary. Buildings should be located based on aerial photographs or using field-based data, but this kind of data is not available in all countries. Various methods corresponding to the generalization of spatial data have been developed to characterize towns: the envelop convex method, Delaunay triangulation, and recently a generalization pattern from the BD TOPO ${ }^{\circledR}$ from the French National Geographical Institute database (Boffer, 2001; Ruas, 1999). The latter method characterized towns as areas that contain similar numbers of buildings, which are merged before simplifying their shape using the mathematical morphology approach developed by Matheron and Serra (1964) and also considers recent studies from Edwards and Regnault (2000). Other authors (Le Corre et al., 2000; Kalhori and Weber, 2005) use mathematical morphology to delineate towns or data aggregation methods based on length criteria.

All these methods are based on specific distances. Some distance concepts are used to discriminate types of dwellings. However, there are no clear guidelines on what distance to use. A buffer distance should include a range of different fire-fighting objectives. Theobald and Romme (2007) assumed an 80 metres radius "firewise" treatment zone around each housing unit (defensive space). Cohen (2000) proposed a distance of 40 metres as "the likelihood of it being destroyed in a wildfire”. In understanding which factors influence building density and fragmentation, Gonzalez-Abraham et al. (2007) applied 50, 100 and 250 metres disturbance zones around each building. Stewart et al. (2007) chose a 1.5 mile buffer distance based on the estimation of how far a firebrand can fly. Other methods combine both density and spatial patterns of buildings (Theobald et al., 1997). Despite the significance of the WUI concerns, particularly in land and fire management (Radeloff et al., 2005b; Zhang and Winberly, 2007), empirical data on its extent and location are lacking.

\section{An exploratory process to identify types of dwelling}

The first approach was to assume that dwelling types can be discriminated according to housing density values. One easy method was to use the existing density function of the Spatial Analyst extension of Arcgis ${ }^{\circledR} 9.1$ software (Lampin et al., 2007). The size of the radius corresponds to the extension of the wildland-urban interfaces (Lampin et al., 2006a, 2006b). The result is relatively easy to obtain because of the existing function in the software, which is an advantage, but the cartographic figuration is not completely satisfactory. Indeed a house and its surrounding 100 metres (wildland-urban interface delimitation) was not always classified as belonging to only one type of dwelling, even when we did not use kernel density. In fact, kernel density generally increased the problem of this phenomenon. Part of the area concerned may belong to an isolated dwelling class, whereas another part of the same area may belong to the scattered dwelling class. In addition, calculation of housing density is obviously intuitive. The difficulty lies in particular, in the need to determine the best density thresholds that would allow us to distinguish the different types of dwellings. This depends on urban management decisions 
that may differ with the municipality. This is why we suggest that threshold values should be determined through analysis of the spatial distribution of housing.

The second approach was to consider specific distances between houses to create density classes based on the spatial distribution of houses and to discriminate types of dwellings. Rules referring to basic length concepts relating houses to the urban continuity were set, where these rules were based on existing distance concepts. The French National Institute for Statistics and Economic Studies (INSEE) defined the concept of "urban unit" as all houses located less than 200 metres apart. A distance of 200 metres can easily be covered on foot by anybody who wants to go from one house to another. Beyond 200 metres, a house is considered as an isolated dwelling. The French National Geographical Institute (IGN) created the "urban area" concept (CETE, 2005) in its geographical database BD CARTO ${ }^{\circledR}$. These urban areas are restricted to aggregated areas which correspond to houses located less than 100 metres apart. Using this "urban area" concept, we defined clustered dwellings as houses located less than 100 metres apart. In addition, the generalization pattern from the BD TOPO ${ }^{\circledR}$ (IGN) database (Boffer, 2001; Ruas, 1999) identifies the centre of town by clusters of houses that are less than 50 metres apart. The number of houses can also be taken into account; urban rules consider that houses are clustered when a group contains at least two houses separated by less than 100 metres. The method based on mathematical morphology principles was performed using IMAGE J software. Using specific distances between houses to identify the types of dwellings, the basic mathematical morphology operations (closing and opening) enabled us to discriminate three classes of dwellings (Lampin et al., 2007). This approach provides mean values of housing density based on the spatial distribution of houses which can be used to create thresholds for existing methods or to characterize each type of dwelling. But small clusters of 2 or 3 houses can still appear as isolated dwellings despite a short distance between houses. Regarding the risk of fire, this configuration of houses is as vulnerable as an isolated house. Thus the classification of types of dwellings based only on the house density criterion based on distance between houses is not adequate and requires another approach.

\section{Materials and method}

\subsection{Study area}

The study area (fig.1) is located in south-eastern France near Aix-en-Provence and comprises 64,700 hectares corresponding to 28 municipalities. In this area, wildland-urban interfaces are very common and urban sprawl is replacing agricultural fallows near or within forested areas. The risk of forest fire is particularly high.

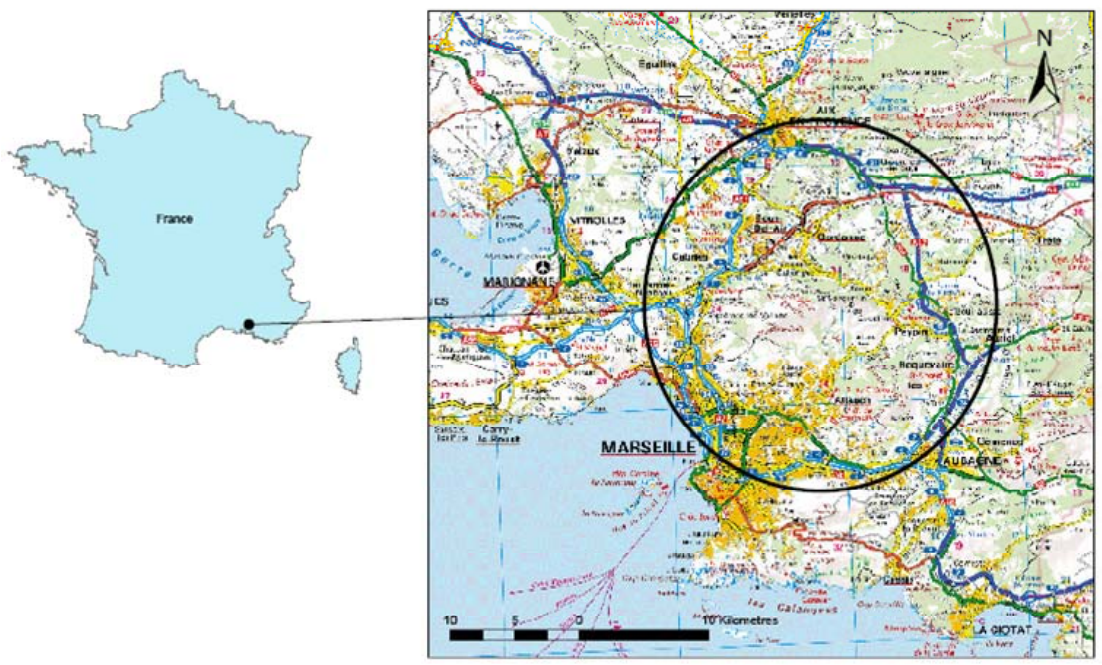

Fig.1 Location of the study area in the south-eastern France 


\subsection{Data, software}

This study used data from the French National Geographical Institute (IGN), housing data from the BD TOPO ${ }^{\circledR}$ database produced in 1992, and aerial photos from the BD ORTHO ${ }^{\circledR}$ database produced in 2003, which have a resolution of 0.50 metres. Concerning housing data, the vector layer of houses was extracted from the 1992 BD TOPO ${ }^{\circledR}$ and updated from the 2003 aerial photos derived from the BD ORTHO ${ }^{\circledR}$. The study is only concerned with residential buildings (dwellings) and includes 50,200 houses on the study site. A digitalized database of fire ignition points was used. This database has been created by the National Forest Institute and counts fire ignition points corresponding to fires that spread over more than one hectare during the period 1996-2007. 227 ignition points are contained in the study area.

One computer program was used to characterize housing types. Arcgis ${ }^{\circledR} 9.1$, developed by ESRI (Environmental Systems Research Institute), enables the user to visualise, explore, and analyse spatial data. It is suitable for vector or raster datasets. We mainly used it to carry out geo-treatment, to combine different layers and to map results.

\subsection{Identification of dwelling types using distance and counting criteria}

The approach was to consider specific distances between houses combined with housecounting criteria. Rules determining basic length concepts between houses and numbers of houses were defined based on existing distance practice in the context of fire prevention. A method based on classical geo-treatment usually performed in Geographical Information System (GIS) was developed. Isolated dwellings (ID) refer to houses (or clusters of 2 or 3 houses) located more than 100 metres apart. This number of houses takes into account fire prevention management; it is difficult to protect houses against fire without endangering fire fighters. Scattered dwellings (SD) correspond to clusters of 4 to 50 houses located less than 100 metres apart. This number of houses refers to a fire-fighting strategy. A fire-fighter team composed of four trucks can protect up to 10 houses if they are located relatively close to one another, less than 100 metres apart. Clustered dwellings (CD) refer to clusters of more than 50 houses located less than 100 metres apart. In this last category, two sub-classes have been determined: a first one identifies dense clustered dwellings (DCD) corresponding to clusters of less than 10 houses located less than 30 metres apart and a second one identifies very dense clustered dwellings (VDCD) corresponding to clusters of more than 10 houses located less than 30 metres apart that being equivalent to well urbanized areas.

Different operations were carried out with Arcgis ${ }^{\circledR} 9.1$ software. Geo-treatment enabled us to create buffers with different diameters (50 metres and 15 metres). The overlaying buffers were merged and the houses within each buffer zone were counted to differentiate housing types according to the rules presented below. For each house of a different class (isolated, scattered or clustered) a buffer of 50 metres was created. To avoid overlaying of buffers, a rule of predominance was established, where the buffer corresponding to the most clustered class took priority.

\subsection{Calculation of spatial criteria related to the risk of forest fire and statistical analysis}

Spatial criteria related to the risk of forest fire were determined for each type of dwelling. Calculations were made for each polygon created in the study area using the buffering process, with a 50-metre radius around each house to discriminate the three main types of dwellings (isolated, scattered and clustered) and a 15-metre radius around each house belonging to clustered dwellings in order to discriminate the two sub classes of clustered dwellings (dense and very dense clustered dwellings). Three indicators were calculated: house density, mean area to be cleared per house (The French Forest Orientation Law of July 112001 makes clearing brush obligatory within a 50-metre perimeter around each house - although the local mayor can extend this limit to 100 metres - located at a distance of less than 200 metres from forest or scrubland) and mean perimeter per house to be protected by firefighters in the case of forest fire. Then, a statistical analysis was performed on the whole of polygons obtained by studying the 
entire study site. The aim was to assess whether there was any statistical difference, not only between the three main dwelling types based on spatial criteria such as housing density, area to be cleared, and perimeter to be protected, but also inside the dwelling cluster variable between dense and very dense clustered dwelling types. This calculation was made with Statgraphics software. Comparisons between the three populations corresponding to isolated, scattered and clustered dwellings were made as well as comparisons between the two sub populations of clustered dwellings, dense and very dense clustered dwellings.

\subsection{Relationships between the distribution of fire ignition points and dwelling types}

Regarding the distribution of fire ignition points in wildland-urban interfaces (WUIs) as a function of different types of dwelling, an indicator of fire ignition density was calculated using the fire ignition point database. This was defined as the ratio of the number of ignition points located within a given area to the surface of this area, and is expressed in the number of fires per 1,000 hectares. We considered different types of territory within the study area: isolated WUIs, scattered WUIs and clustered WUIs, and the remainder of the study area. The surface area of the different types was calculated and the number of fire ignition points located within each part was determined.

\section{Results}

\subsection{Maps of dwelling types based on distance plus counting criteria using GIS}

The process of creating buffer zones, based on both the spatial juxtaposition of houses and on the number of houses, enabled us to create a map of dwelling types using Arcgis ${ }^{\circledR 9} 9.1$ software. This is an efficient method for the characterization of dwelling types: isolated, scattered and clustered dwellings, and has the advantage of being easy to use. The method is based on distance and house-counting criteria using GIS and can thus be applied to large areas (fig.2). Each house belongs to a single dwelling type, as we can see if we zoom in on the map (fig.3). The repartition of polygons according to dwelling types is presented in table 1 . Two sub classes (dense and very dense) were then defined in the clustered dwelling class, by buffering the houses included in the 72 polygons of this class. Fig. 4 compares the result of mapping dwellings with a photo corresponding to the extract of the mapped area. Maps of dwellings were produced easily and can be used in the first step in characterizing and mapping wildland-urban interfaces.

\begin{tabular}{|l|l|}
\hline \multicolumn{2}{|c|}{ Number of identified polygons in the study area } \\
\hline Isolated dwelling (ID) & 979 \\
\hline Scattered dwelling(SD) & 524 \\
\hline Clustered dwelling(CD) & 72 \\
\hline$\longrightarrow$ Dense clustered dwelling (DCD) & 477 \\
\cline { 2 - 2 } Very dense clustered dwelling (VDCD) & 742 \\
\hline
\end{tabular}

Table 1 Number of identified polygons in the study area 


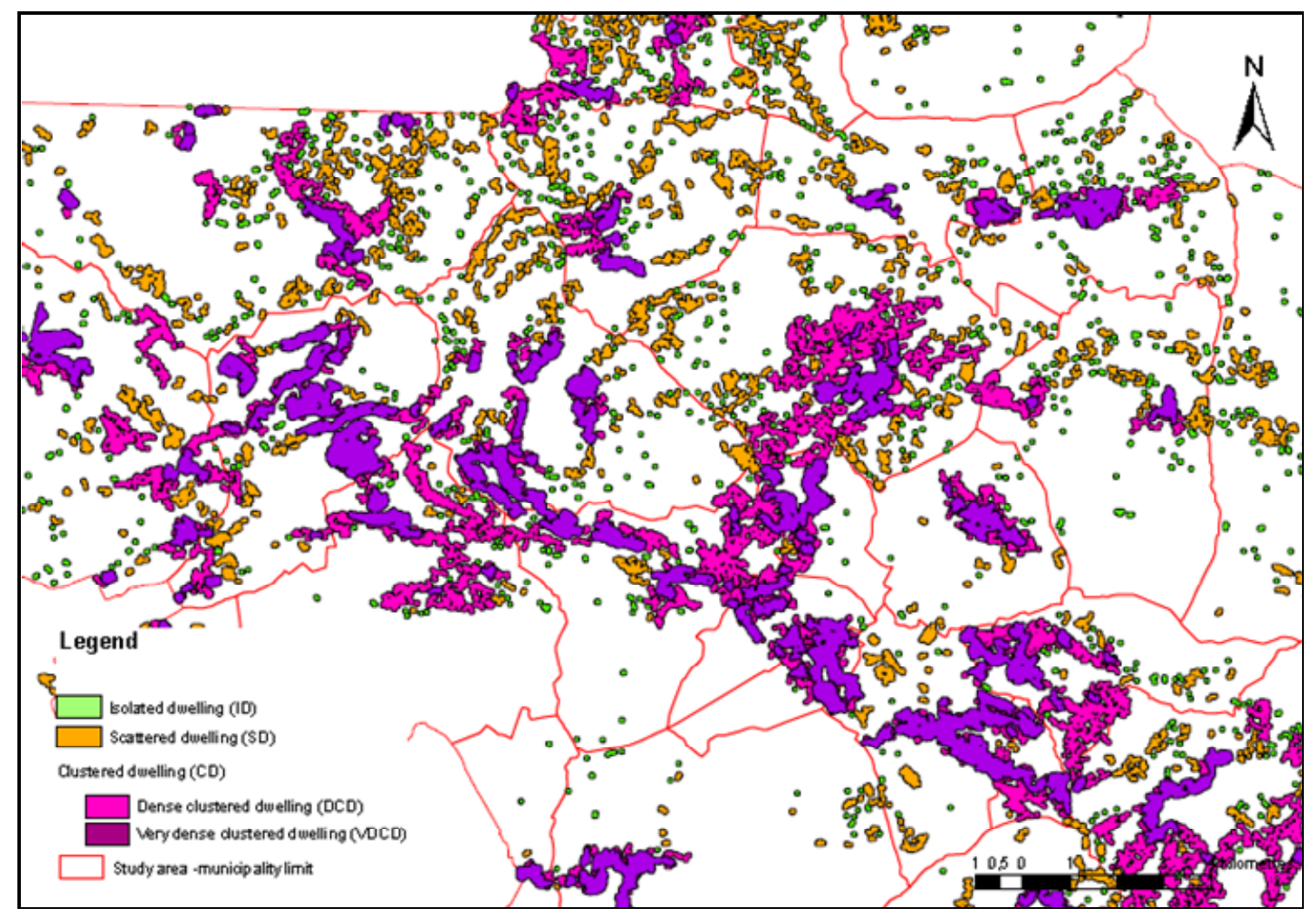

Fig.2 Dwelling type map in the study area

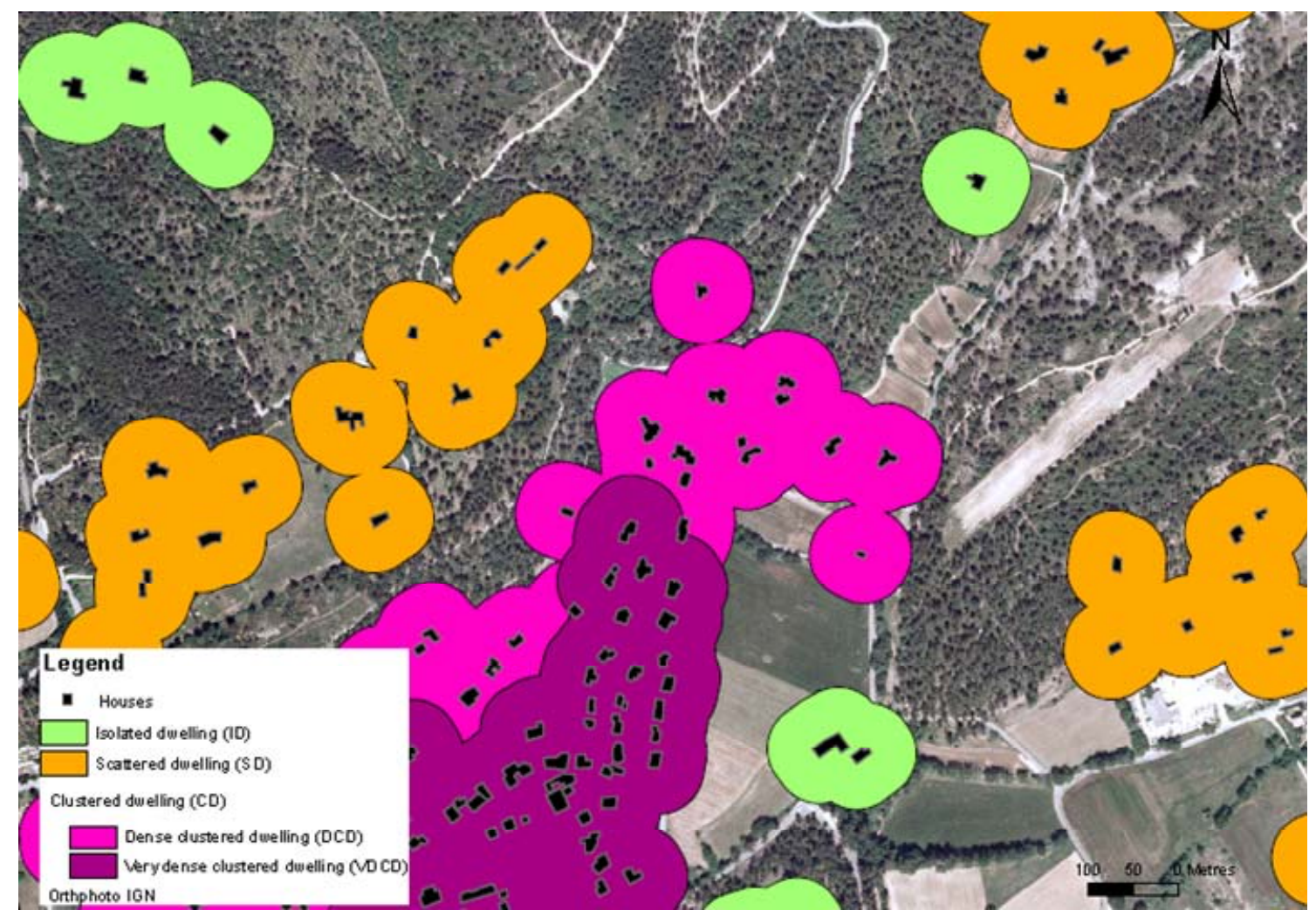

Fig.3 Details of dwelling type map 


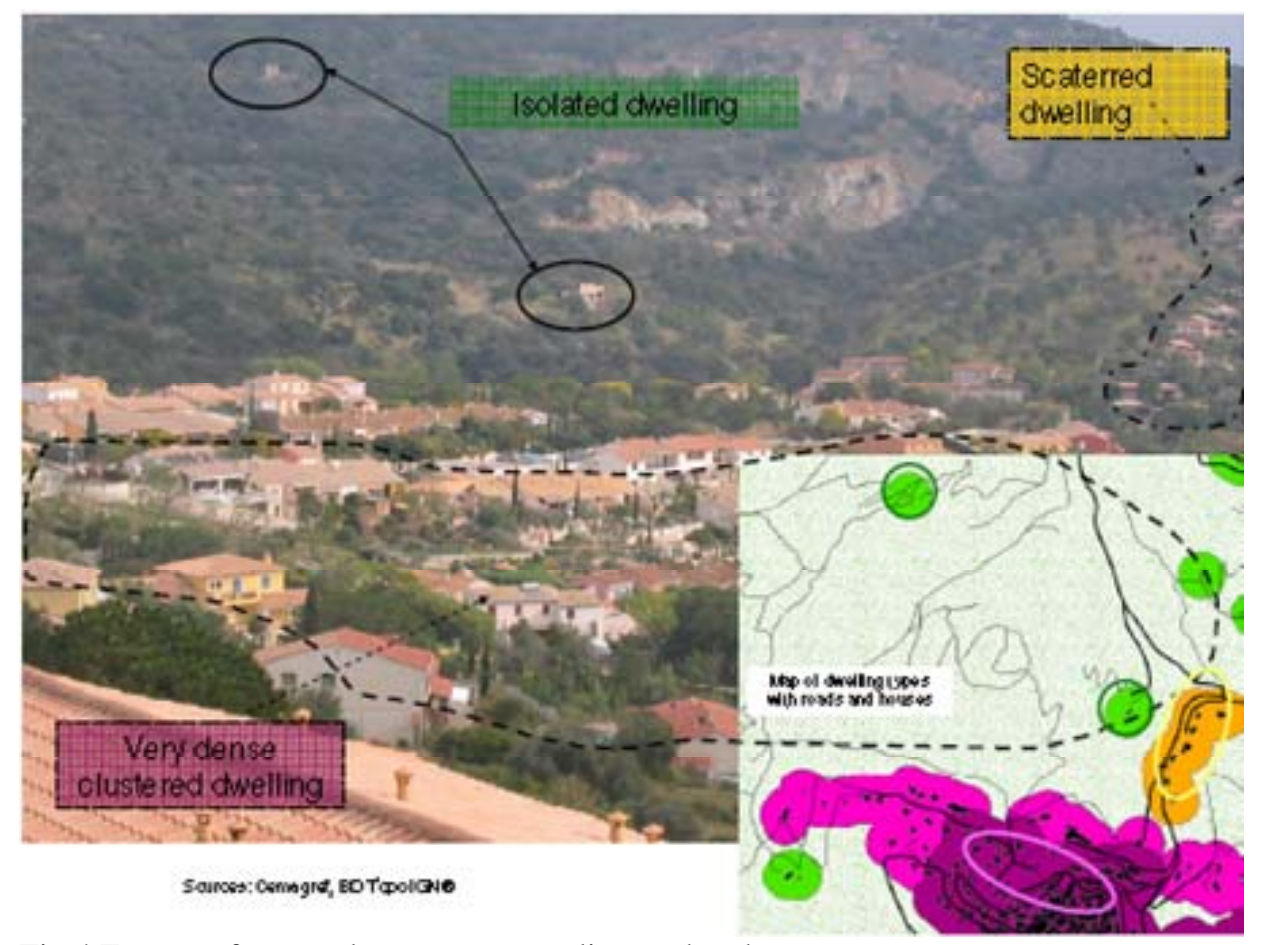

Fig.4 Extract of mapped area corresponding to the photo

\subsection{Dwelling types statistically different according to spatial criteria related to the risk of forest fire}

Over the whole of the study area, the three populations corresponding to isolated dwellings (ID), scattered dwellings (SD) and clustered dwellings (CD) have been compared for each spatial criterion: mean housing density, mean area to be cleared and mean perimeter to be protected. The number of observations (corresponding to polygons) is 979 for the isolated dwelling population, 524 for the scattered dwelling population and 72 for the clustered dwelling population. A box plot comparing the three dwelling types for mean housing density (fig.5.1), mean area to be cleared (fig.5.3) and mean perimeter to be protected (fig.5.5) shows that the type of dwelling has a significant effect on each response variable. Isolated dwellings have the highest mean area to be cleared and mean perimeter to be protected and the lowest mean housing density. In contrast, clustered dwellings have the lowest mean area to be cleared and mean perimeter to be protected and the highest mean housing density. Figures 5.1 to 5.6 present box plots, from left to right and from top to bottom, calculated for spatial criteria and different dwelling types (ID, SD CD and DCD, VDCD).

The two populations corresponding to the sub classes of clustered dwellings, dense clustered dwellings (DCD) and very dense clustered dwellings (VDCD) have been compared for each spatial criterion: mean housing density, mean area to be cleared and mean perimeter to be protected. The number of observations (polygons) is 411 for the dense clustered dwelling population and 142 for the very dense clustered dwelling population. As before, the box plots, comparing the two clustered dwelling types (dense and very dense) for mean housing density (fig.5.2), for mean area to be cleared (fig.5.4) or for mean perimeter to be protected (fig.5.6) show that the type of dwelling has a significant effect on response variable. Dense clustered dwellings have the highest mean area to be cleared and mean perimeter to be protected and the lowest mean housing density. In contrast, very dense clustered dwellings have the lowest mean area to be cleared and mean perimeter to be protected and the highest mean housing density. 

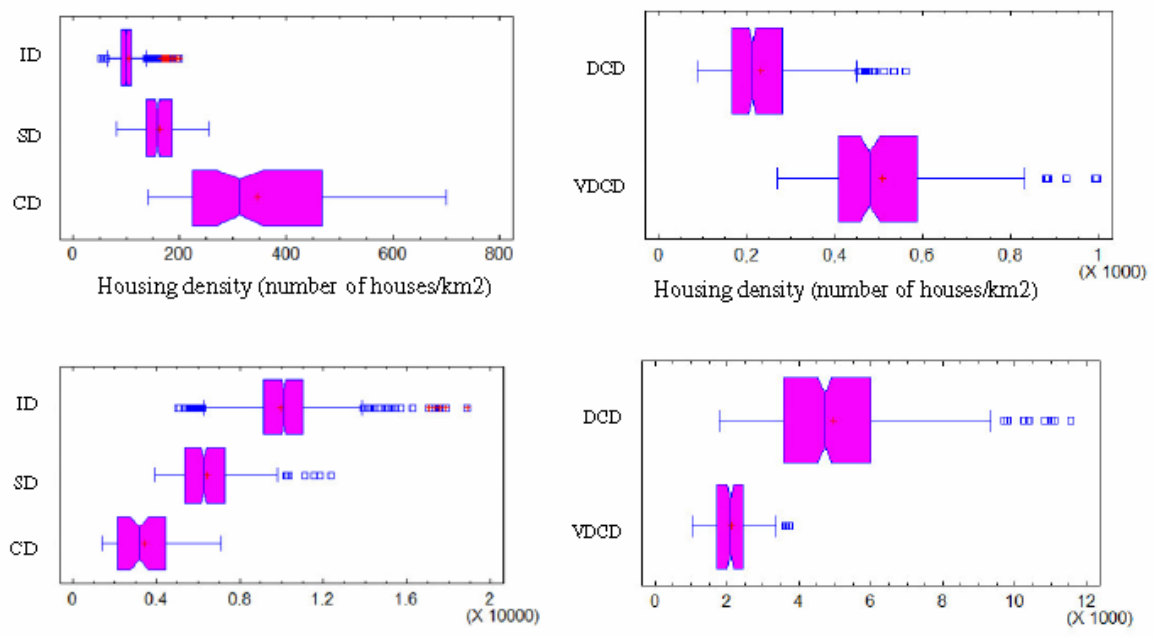

Area to becleared (m2)

Area to be cleared (m2)
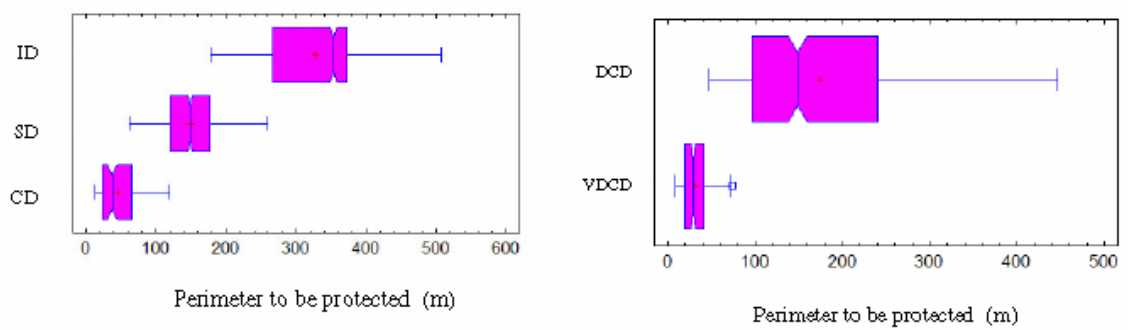

Fig.5 (1)-(6) Box plots (left to right, top to botton)

Results confirmed that there were highly significant differences between the different types of dwellings. The non-parametric Kruskall-Wallis test was used to test both the difference between the three main classes of dwelling (isolated, scattered and clustered dwellings) and between the two sub classes of clustered dwelling (dense and very dense clustered dwelling). In each case the probability value is less than 0.05 . As a result, there is a statistically significant difference for each criterion not only between the three main types of dwelling, but also between the two sub classes of clustered dwelling. Corresponding to highly statistically different types of dwelling, each of them has been characterized by their statistical values. Table 2 summarizes the main statistical values for housing density, area to be cleared and the perimeter to be protected for each type of dwelling. The actual values are presented in table 2 as: median-mean (standard deviation), minimum- maximum.

\begin{tabular}{|c|c|c|c|c|c|}
\hline Dwelling types & $\begin{array}{l}\text { Number } \\
\text { of } \\
\text { polygons }\end{array}$ & $\begin{array}{c}\text { Number of } \\
\text { houses }\end{array}$ & $\begin{array}{c}\text { Housing } \\
\text { density } \\
\text { (number of } \\
\text { houses per } \mathrm{km}^{2} \text { ) }\end{array}$ & $\begin{array}{l}\text { Area to be } \\
\text { cleared per } \\
\text { house (ha) }\end{array}$ & $\begin{array}{l}\text { Perimeter to be } \\
\text { Protected per } \\
\text { house (m) }\end{array}$ \\
\hline $\begin{array}{l}\text { Isolated } \\
\text { dwelling (ID) }\end{array}$ & 979 & $\begin{array}{c}1-1.4 \mid(1) \\
(1-3)\end{array}$ & $\begin{array}{c}99-\mathbf{1 0 4}(23) \\
(53-199)\end{array}$ & $\begin{array}{l}1-1(0.2) \\
(0.5-18.9)\end{array}$ & $\begin{array}{c}353-328(67) \\
(178-507)\end{array}$ \\
\hline $\begin{array}{l}\text { Scattered } \\
\text { dwelling (SD) }\end{array}$ & 524 & $\begin{array}{l}6-9(9) \\
(3-50)\end{array}$ & $\begin{array}{c}159-163(35) \\
(81-256)\end{array}$ & $\begin{array}{c}0.63-0.64 \\
(0.14) \\
(0.4-1.2)\end{array}$ & $\begin{array}{c}149-149(39) \\
(62-260)\end{array}$ \\
\hline $\begin{array}{l}\text { Clustered } \\
\text { dwelling (CD) }\end{array}$ & 72 & $\begin{array}{c}170-332 \\
(482) \\
(51-2614) \\
\end{array}$ & $\begin{array}{c}313-346(144) \\
(141-700)\end{array}$ & $\begin{array}{c}0.32-0.34(0.1) \\
(0.1-0.7)\end{array}$ & $\begin{array}{l}38-46(27) \\
(14-119)\end{array}$ \\
\hline $\begin{array}{l}\text { Dense } \\
\text { ciustered } \\
\text { dwelling } \\
(D C D)\end{array}$ & 411 & $\begin{array}{c}5-22(70) \\
(1-973)\end{array}$ & $\begin{array}{c}212-233(92) \\
(86-560)\end{array}$ & $\begin{array}{c}0.47-0.49 \\
(0.18) \\
(0.18-1.1)\end{array}$ & $\begin{array}{c}148-176(96) \\
(47-446)\end{array}$ \\
\hline $\begin{array}{l}\text { Very dense } \\
\text { ciustered } \\
\text { dwelling } \\
(V D C D)\end{array}$ & 142 & $\begin{array}{c}53-153(288) \\
(10-2135)\end{array}$ & $\begin{array}{c}479-507(150) \\
(267-995)\end{array}$ & $\begin{array}{c}0.20-0.21 \\
(0.06) \\
(0.1-0.37)\end{array}$ & $\begin{array}{c}29-32(15) \\
(9-74)\end{array}$ \\
\hline
\end{tabular}

Table 2 Characteristics of dwelling types 


\subsection{Localisation of fire ignition points as a function of type of dwelling.}

The mean fire ignition density value was calculated for the whole Aix-en-Provence study area for the period 1996-2007. This value reached 3.5 fire ignition points per 1,000 hectares. The same value was calculated specifically for wildland-urban interfaces, and proved to be 1.5 times higher in wildland-urban interfaces than elsewhere with 5.3 fire ignition points per 1,000 hectares (fig.6). Our results show that fire frequency is very much higher in WUI areas than in natural areas. In addition, the fire ignition density was calculated for each of the dwelling types. Within dwelling types, we observed that the density value was two times higher for isolated dwellings than for clustered dwellings. Specifically, fire ignition density values increased greatly from clustered dwellings (4.2 fire ignition points per 1,000 ha), to scattered dwellings (5.2 fire ignition points per 1,000 ha) and finally to isolated dwellings (9.5 fire ignition points per 1,000 ha). This suggests that the spatial pattern of dwellings has a real impact on fire occurrence. Humans, and their spatial distribution, explain a part of the variability in the number of ignition points.

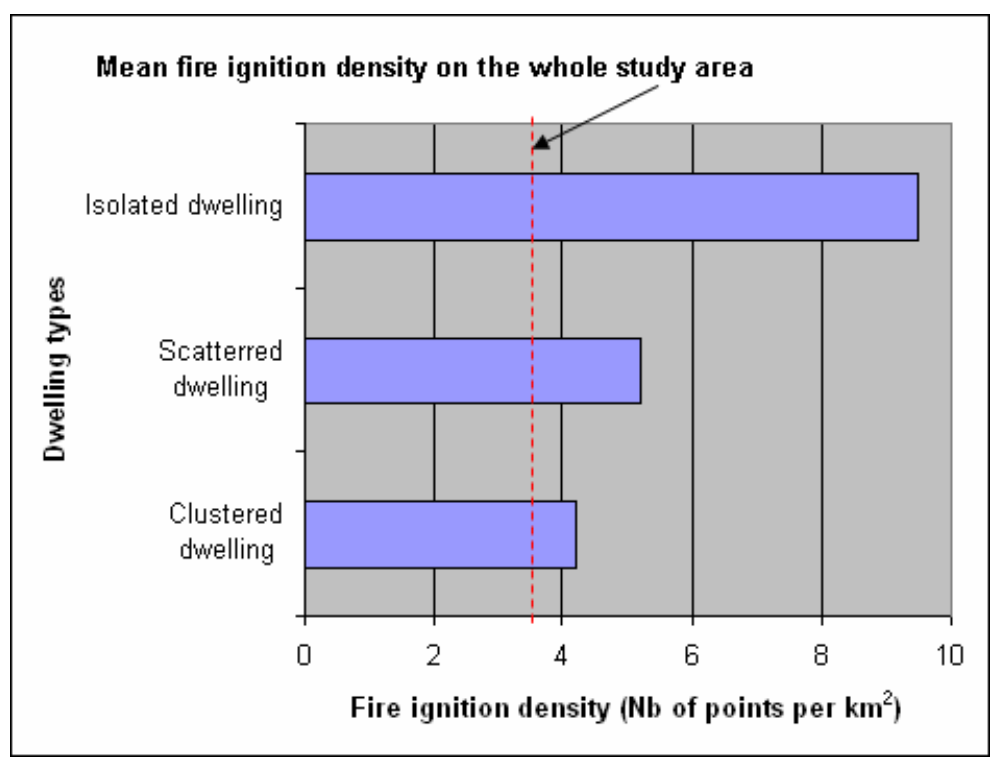

Fig.6 Fire ignition density value

\section{Discussion-Conclusions}

The method developed to characterize dwelling types seems to be efficient, using GIS treatment based on the two following criteria: distance between houses and counting houses located close together. Moreover, this method is easy to use, can be transferred to land agencies or managers and can be applied to large areas on the scale of forest stands or several communities. The maps that can be produced using this method fulfil the needs of the main endusers concerned with forest fire prevention and forest fire-fighting. Indeed end-users such as forest and land planning managers or forest fire-fighters are interested in the location of wildland-urban interfaces that are directly related to different types of dwellings in contact with vegetation. Maps of different dwelling types can be interpreted for use in developing firefighting strategies or fire prevention measures.

Main criteria were defined: housing density, area to be cleared and the perimeter to be protected for each housing category. These criteria allow managers and fire-fighters to measure the effects of the dwelling structure on prevention measures or fire-fighting actions. It will be more difficult to protect isolated dwellings whose protection perimeter is almost ten times larger than the perimeters for clustered dwellings. It will be more difficult for a home owner to keep a large area around an isolated dwelling clear where this is three times more important than in a 
clustered dwelling. The mean density values that discriminate the three dwelling types proposed are approximately 100 houses per square kilometre for isolated dwellings, 160 houses per square kilometre for scattered dwellings, and 345 houses per square kilometre for clustered dwellings. These density values can be compared to thresholds defined in previous studies concerned with wildland-urban interface density values. Theobald (2001) and Stewart et al. $(2003,2007)$ fixed two thresholds to differentiate wildland urban areas with a minimum housing density of 6 houses per square kilometre for WUI from urban areas with a housing density over 148 houses per square kilometre. Other thresholds were used by Hammer et al. (2004), for whom the lowest-density rural clusters remain below 2 housing units per square kilometre, while the highest density category was more than 128 units per square kilometre. These thresholds can be combined with thresholds obtained with the density function (Lampin et al., 2007): less than 48 houses per square kilometre for isolated dwellings, around 48 to 160 houses per square kilometre for scattered dwellings, and more than 160 houses per square kilometre for clustered dwellings, where the highest values are relatively similar and the lowest values are different. This result is congruent with the low values obtained with the mathematical morphology approach (Lampin et al., 2007). Values obtained with our presented method are higher than the values specified in the methods. We can suppose both that the delimitation of the area that is the basis of the density calculation plays an important role in explaining this gap and that land cover and landscape are probably highly different.

The analysis of the spatial distribution of the fire ignition points shows a clear and positive relationship with the wildland-urban interface, as in Badia-Perpinya and Pallares-Barbera (2006). The results also show significant differences between the dwelling types. The spatial housing pattern influences the frequency of fire ignitions as in Cardille et al. (2001) and Pew and Larsen (2001). We point out that a lower housing density is connected with a higher number of fire ignition points. This is in accordance with the results of Syphard et al. (2007a), who used fine-resolution maps of WUI from housing density and land cover data. They showed that lowdensity housing explained significant variation in the number of fires.

In terms of fire management, these results should prove useful in identifying different dwelling types, which are an extremely important component of fire risk, in terms of the following two elements: hazard and vulnerability (Jappiot et al., 2001; Blanchi et al., 2002). Fire risk variables can be associated to two main groups: physical variables and human variables (Amatulli et al., 2006). Dwelling density has only a small influence on fire risk when considered in the context of the number of possible socio-economic factors linked with the occurrence of wildfires (Romero-Calcerrada et al., 2008). According to Syphard et al. (2007b), ignition sources are linked to the spatial arrangement of dwellings and continuous vegetation. Other biophysical variables such as elevation and fuel types should be combined with the dwelling types in order to assess overall fire risk. Risk assessment could also be improved by including other socio-economic factors such as distance to the nearest road, population density, and others. In terms of public policy, introducing the risk of fire, and particularly the vulnerability of the territory using maps of dwelling types, is a way to make the inhabitants more aware of fire risk in WUI. This will globally decrease the risk of fire (i) by reducing fire propagation via biomass removal, and (ii) by reducing fire ignition probability by encouraging less carelessness. Accomplishing this goal is strictly related to the designation of suitable prevention messages and preventive measures which can be different according to WUI types. An important land use management implication of these results is to use this approach to measure urban sprawling, and to provide some suggestions to recommend where to encourage compact urban development. This is one of the current applications in France, namely to use this kind of map in Prevention Plans at the municipality level. Moreover, as Romero-Calcerrada et al. (2008) pointed out, these results could possibly be useful to fire managers, in order to concentrate their forces near the riskiest areas, and to thereby be able to attack a fire as quickly as possible. Finally, the qualification of dwelling types is one of the main elements of the characterization of wildland-urban interfaces, where this is crucial for the improvement of forest fire prevention and fire-fighting. 


\section{Acknowledgments}

The work was partially financed by the French "Ministère de l'Ecologie, du Développement et de l'Aménagement Durables”, “Conseil Régional Provence-Alpes-Côte-d'Azur”. The authors wish to thank them. They also acknowledge J.C.Thill for reviewing the final manuscript and the anonymous peer reviewers for their comments, the firefighters of the "Service d'Incendie et de Secours du Var", and the foresters of the "Direction Territoriale Méditerranée de l'ONF" for their contribution.

\section{References}

Alberti, M., Booth, D., Hill, K., Coburn, B., Avolio, C., Coe, S., Spirandelli, D. (2007). the impact of urban patterns on aquatic ecosystems: an empirical analysis in Puget lowland sub-basins. Landscape and Urban planning 80, pp 345-361.

Amatulli, G., Rodrigues, M.J;, Trombetti, M., Lovreglio, R. (2006). Assessing long-term fire ris kat local scale by means of decision tree technique. Journal of geophysical research, 111GS04S05.

Avalapati, J.R.R., Carter, D.R., Newman, D.H. (2005). Wildland-Urban Interface: challenges and opportunities. Forest Policy and Economics, 7, pp 705-708.

Badia-Perpinya, A and Pallares-Barbera, M. (2006). Spatial distribution of ignitions in Mediterranean periurban and rural areas: the case of Catalonia. International journal of Wildland fire, 15, pp 187-196.

Blanchi R., Jappiot, M., Alexandrian D. (2000). Forest fire risk assessment and cartography. A methodological approach. Proceedings of the IV International Conference on Forest Fire Research - 18 novembre au 22 novembre 2002, Luso (Portugal).

Boffer, A. (2001). Méthode de création d’information multi niveaux pour la généralisation cartographique de l'urbain. Thèse de doctorat. Université de Marne La Vallée.

Canicio-Voiron, C. (1995). Morphologie d'un semis de villes européennes. Mappemonde 4/95. pp17-21.

CETE Lyon, CERTU. (2005). Les bases de données géographiques d'occupation du sol : Volet tâche urbaine. Descriptif et comparatif de 6 bases de données. Available from $<$ http://www.certu.fr $>$.

Church, R.L., Cova, T.J. (2000). Mapping evacuation risk on transportation networks using a spatial optimization model. Transportation Research Part C, 8, pp 321-336.

Cohen, J.D. (2000). "Preventing disaster: Home ignitability in the wildland-urban interface." Journal of Forestry 98(3): 15-21.

Conard, S.G., Hartzell, T., Hilbruner M.W., Zimmerman, G.T. (2001). Changing fuel management strategies - The challenge of meeting new information and analysis needs. International Journal of Wildland Fire, 10, pp 267-275.

Curtis, P.D., Richmond, M.E., Wellner, P.A., Tullar, B. (1995). Characteristics of the private nuisance wildlife control industry in New York. Proc. East. Wildl. Damage Control Conf., 6, pp 49-57.

Davis, J. (1990). The wildland-urban interface: Paradise or battleground? J. For. 88: 26 -31.

Edwards, A., Regnault, N. (2000). Preserving the pattern of density in urban network simplification. Proceedings of the first International Conference on Geographic Information Science, Savannah, USA,

Fisher, R., Perkins, S., Walker, A., Wolfart, E. (2003). Hypermedia Image Processing Reference, Available from<http://homepages.inf.ed.ac.uk/rbf/HIPR2/copyrght.htm>.

Gonzalez-Abraham, C.E, Radeloff, V.C., Hammer, R.B. (2007). Building patterns and landscape fragmentation in northern Wisconsin, USA. Landscape Ecology, 22, pp 217-230.

Hammer, R.B., Stewart, S.I., Winkler, R.L., Radeloff, V.C. Voss, P.R. (2004). Characterizing dynamic spatial and temporal residential density patterns from 1940-1990 across the North Central United States. Landscape and Urban Planning, 69, pp 183-199.

Jappiot, M., Blanchi, R., Guarnieri, F. (2001).Traité IGAT "Information géographique et aménagement du territoire", "Aménagement et gestion des territoires", Vol. "Gestion spatiale des risques", Ch.apitre 6 "Systèmes d'information géographique et modélisation dans le domaine de la prévention des incendies de forêt". Brugnot G. Dir Lavoisier Editions Hermès Sciences Publications, Paris, pp 145-181.

Johnson, M. P. (2001). Environmental impacts of urban sprawl: a survey of the literature and proposed research agenda. Environment and Planning A 33:717-735.

Kalhori, A., Weber, C. (2005). Sectorisation de la qualité de l'air. Colloque international de géomatique SAGEO. Avignon, 21/22/23 juin 2005.

Kamp, M. and Sampson, N. (2003). Using GIS to identify potential Wildland-Urban Interface areas based on population density. Available on line at <www.sampsongroup.com/Papers/wui_paper.pdf>. 
Lampin, C., Long, M., Jappiot, M., Morge, D. 2007. Dwellings characterization and mapping for forest fire risk prevention. UDMS annual 2007. Proceedings of the urban data management society symposium 2007. Stuttgart, Germany, 10-12 october 2007. pp 427-440.

Lampin, C., Jappiot, M., Borgniet, L., Long, M. (2006a). Cartographie des interfaces habitat-forêt : une approche spatiale pour estimer le risque d'incendie de forêt. Revue internationale de géomatique. European Journal of GIS and Spatial analysis. Information géographique et gestion des risques. Vol.16- n³-4/2006-pp321-340. 2006.

Lampin, C., Jappiot, M., Long, M., Mansuy, N., Borgniet, L. (2006b). WUI and road networks/vegetation interfaces characterizing and mapping for forest fire risk assessment. V Conference international on Forest fire research. 27-30 november. Portugal Forest Ecology and Management Volume 234, Supplement 1 pp. S42. 2006

Le Corre, S., Guillaume, R., Galaup, M., Boissezon, H. (2000). Intérêts et limites de l'utilisation des images satellites en vue de la constitution d'un SIG pour la région urbaine d'Istanbul. Acte de colloque « Représenter Istanbul hier et aujourd’hui », 19 et 20 mai 2000, Istanbul.

Lepczyk, C.A. and Hammer, R.B. (2007). Spatiotemporal dynamics of housing growth hotspot in the North Central U.S from 1940 to 2000. Landscape Ecology, 22, pp 939-952.

McKinney, M. L. (2002). Urbanization, biodiversity, and conservation. BioScience 52:883-890.

Matheron, G., Serra, J. (1964). The birth of mathematical morphology. Proc. 6th Intl. Symp. Mathematical Morphology. Csiro Publishing.

Promethée database. Base documentaire. Statistiques et bilans. Prométhée Available from $<$ http://www.promethee.com>.

Radeloff, V.C., Hammer R.B., Stewart ,S.I. (2005a). Rural and suburban sprawl in the U.S. Midwest from 1940 to 2000 and its relations to forest fragmentation. Conserv. Biol. 19 (3): pp793-805.

Radeloff, V.C., Hammer R.B., Stewart ,S.I., Fried, J.F., Holcomb, S.S. McKeefry, J.F. (2005b). The wildland-urban interface in the United States. Ecological applications 15 (3), pp 799-805.

Ridd, M.K. (1995). Exploring a V-I-S (vegetation-impervious surface soil) model for urban ecosystem analysis through remote sensing : Comparative anatomy for cities. Int. J. Remote Sensing 1- (2), pp 2165-2185.

Romero-Calcerrada, R., Novillo, C.J., Millington, J.D.A., Gomez-Jimenez, I. (2008) ; Gis analysis of spatial patterns of human-caused wildfire ignition risk in the SW of Madrid (central Spain). Landscape Ecology, 23, pp 341-354.

Ruas, A. (1999). Modèle de généralisation de données géographiques à base de contraintes et d'autonomie. Thèse de doctorat. Université de Marne La Vallée. Available on line at $<\mathrm{ftp}$ :/ftp.ign.fr/ign/generalisation/COMMUNICATIONS/THESES/RUAS>.

Soulé, M. E. (1991). Land-use planning and wildlife maintenance: guidelines for conserving wildlife in an urban landscape. Journal of the American Planning Association 57: 313-323.

Stephens, S.L. (2005). Forest fire causes and extent on United State Forest Service lands. Int. J. Wildland Fire, 14, pp 213-222.

Stewart, S.I., Radeloff, V.C. and Hammer R.B. (2003). Characteristics and location of the WildlandUrban-Interface in the United States, pp. 6.

Stewart, S.I., Radeloff, V.C., Hammer, R.B., Hawbaker, T.J. (2007). Defining the Wildland-Urban Interface. Journal of Forestry, pp 201- 207.

Syphard, A.D., Clarke, K.C, Franklin, J. (2007a). Simulating fire frequency and urban growth in southern California coastal shrublands, USA. Landscape ecology, 22. pp431-445.

Syphard, A.D., Radeloff, V.C., Keeley, J.E., Hawbacker, T.J., Clayton, M.K., Stewart, S.I, Hammer, R.B. (2007b). Human influence on California fire regimes. Ecological applications, 17(5), pp 1388-1402.

Theobald, D. M. (2001). Land-use dynamics beyond the American urban fringe. Geogr. Rev. 91 (3), pp 544-564.

Theobald, D. M., J. R. Miller, and N. T. Hobbs. (1997). Estimating the cumulative effects of development on wildlife habitat. Landscape and Urban Planning 39:25-36.

Theobald, D.M. and Romme, W.H. (2007). Expansion of the US wildland-urban interface. Landscape and Urban Planning, 83, pp340-354.

Vince, S.W., Duryea, M.L.; Macie, E.A.; Hermansen, L.A. (2005). Forests at the wildland-urban interface: conservation and management (Boca Raton, CRC Press).

Zhang, Y. and Winberly, M.C. (2007). The importance of scale in using hierachical Census data to identify the Wildland-Urban interface. South. J. Appl. For. 31(3), pp 138-147. 